\title{
Kota Yogyakarta Dan Beberapa Kota Pendahulunya
}

\section{Inajati Adrisijanti}

Keywords: urban archaeology, mataram, islam, history, ancient city

\section{How to Cite:}

Adrisijanti, I. (1998). Kota Yogyakarta Dan Beberapa Kota Pendahulunya. Berkala Arkeologi, 18(2), 23-35. https://doi.org/10.30883/jba.v18i2.781

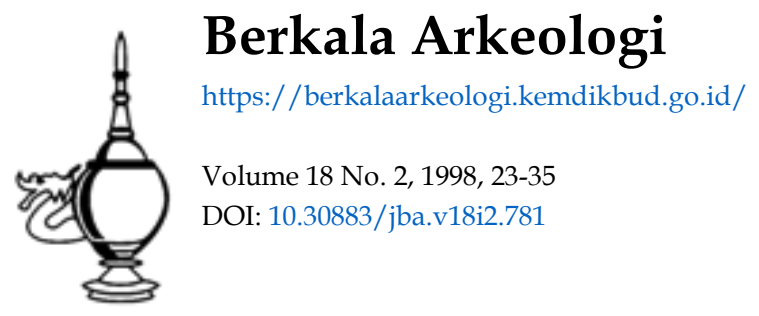

\section{c) (i) (5)}

This work is licensed under a Creative Commons Attribution-NonCommercial-ShareAlike 4.0 International License. 


\title{
KOTA YOGYAKARTA DAN BEBERAPA KOTA PENDAHULUNYA*
}

\author{
Inajati Adrisijanti Romli \\ (Jurusan Arkeologi Fakultas Sastra UGM)
}

\section{A. Pengertian Kota}

Di dalam kesasteraan Jawa Kuno kuta berarti benteng, istana yang mempunyai tembok keliling, tempat pertahanan, dan tembok keliling (Zoetmulder, 1982: 938). Ada beberapa nama tempat yang menggunakan kata kuta yang mengesankan adanya tembok keliling, misalnya: Kuta Renon di Lumajang, dan Kuta Kosod di Cirebon.

Para ahli mengajukan berbagai definisi atau pengertian tentang kota ditilik dari bidang keahlian masing-masing. Ahli sosiologi umumnya memandang kota sebagai suatu permukiman yang permanen, luas, dan padat dengan penduduk yang heterogen (Sirjamaki, 1964: 407). Mata pencaharian penduduk kota terutama adalah membuat dan mempertukarkan barang dan jasa. Weber (1956: 66 - 67) berpendapat bahwa kota adalah pusat kegiatan perekonomian.

Dengan tidak mempcrpanjang bahasan tentang berbagai teori mengenai kota, maka yang perlu mendapat perhatian adalah bahwa kehidupan kota yang majemuk dapat dibuktikan dari data arkeologi dan konteks lingkungannya. Kompleksitas kota menciptakan pengelompokan-pengelompokan penduduk dan pemukimannya, sesuai dengan antara lain asal-usul, latar belakang ekonomi, dan status sosial. Pengelompokan-pengelompokan itu menjadi bagian yang tidak terpisahkan dari suatu kota, dan memiliki nama-nama serta batas-batas tersendiri. Penempatan kelompokkelompok ini akan terlihat dalam tata ruang kota yang bersangkutan.

Tata kota adalah ekspresi sistem keagamaan, budaya, sosial, serta interaksi dengan lingkungan, dalam bentuk material. Oleh karena itu, untuk menemukan gambaran fisik kota dan mengenali morfologinya, perlu dipelajari lay-out kota, yang pada gilirannya merekam organisasi ruang, dan topografinya. Pada masa lalu, proses tenvujudnya tata kota berjalan setahap demi setahap sehingga dapat dikenali uruturutan dalam pembentukan atau pembangunan kota (Elisseff, 1976: 90).

Kota kuno Islami memiliki beberapa faktor yang berkaitan dengan unsur-unsur kota, dan penataannya, yaitu:

1. faktor religi yang diwakili antara lain oleh masjid, baik yang berada di civic center maupun yang berada di kampung-kampung, dan pemakaman-pemakaman;

- Makalah ini pernah dipresentasikan pada Seminar Sehari Arkeologi Perkotaan Sebagai Asset Pariwisata Yogyakarta, di Benteng Vredeburg, 28 Jusi 1990 
2. faktor ekonomi yang diwujudkan dalam bentuk pasar, kelompok undagi, dan profesi lainnya;

3. faktor organisasi politik, dan sosial yang tercermin dari adanya istana, kelompok birokrat, dan kelompok-kelompok masyarakat lainnya;

4. faktor intelektual yang ditampilkan dalam bentuk madrasah yang didirikan oleh pemuka agama;

5. faktor pertahanan-keamanan yang dapat berbentuk benteng, parit pertahanan, serta desa pertahanan;

6. faktor pemenuhan kebutuhan hidup penduduk yang diwujudkan antara lain dalam bentuk tempat bermukim, pengadaan air bersih, drainage, serta jaringan jalan.

Pertumbuhan kota dan urbanisasi dewasa ini sering dianggap sebagai indikator kemajuan, dan modernisasi. Proses pertumbuhan kota dan urbanisasi di Indonesia sering diikuti oleh timbulnya persoalan-persoalan sosial dan budaya (Suryo, t.t.:1). Demikian pula, dari segi sosiologis sukar dilihat dan digambarkan secara lengkap situasi kota-kota kuno yang tcrus tumbuh, baik dari segi struktur fisik, maupun sosialnya. Hal ini dikarenakan banyaknya bangunan yang kemudian mendesak, menutupi, bahkan menggeser bangunan kuno yang merupakan bagian dari struktur fisik kota kuno tersebut. Pergeseran-pergeseran semacam itu juga dialami, atau terjadi dalam struktur sosial penghuni kota sehingga terjadi pula perubahan-perubahan yang sering mengaburkan struktur sosial yang bersangkutan.

\section{B. Kota Yogyakarta}

Dengan ditandatanganinya Perjanjian Giyanti pada tanggal 13 Februari 1755, maka kerajaan Mataram-Islam secara fisik dibagi dua (Ricklefs, 1974: 71). Demikian pula, penduduknya serta benda-benda pusaka kerajaan juga dibagi dua. Pangeran Mangkubumi, sebagai sultan baru, kemudian bergelar Kangjeng Sultan Hamengkubuwana Senapati Ingalaga Ngabdurahman Sayidin Panatagama Kalipatulah (untuk selanjutnya, di dalam tulisan ini disebut HB). Langkahnya yang berikut adalah memilih lokasi untuk kraton yang banı.

Untuk keperluan tersebut di atas hutan Bering-lah yang dipilih, karena di tempat itu sudah ada pesanggrahan yang dinamai Garjitawati (Darmosugito, 1956: 13). Akan tetapi, Sultan HB I untuk sementara menetap di Kraton Pasanggrahan Ambarketawang di Gamping, sebelum kraton selesai dibangun (Ricklefs, 1974: 79; Poensen, 1901: 266). Peristiwa pembangunan kraton Yogyakarta ini ditandai dengan sengkalan memet: Dwi naga rasa tunggal, yang berarti tahun $1682 \mathrm{AJ}=1756 \mathrm{M}$. 
Sultan HB I banyak melakukan pembangunan fisik kota sehingga permukiman yang tentunya semula kecil, dengan segera berkembang menjadi suatu ibukota. Pembangunan-pembangunan tersebut berjalan secara berkesinambungan, contohnya:

1. tembok keliling kraton dibangun pada tahun 1766;

2. Prabayeksa dan Sitinggil Ler dibangun pada tahun 1769 ;

3. Masjid Agung dibangun pada tahun 1773; dan

4. benteng Belanda dan Panggung Krapyak dibangun pada tahun 1788.

Wilayah kota Yogyakarta dibelah oleh aliran sungai Winanga, sungai Code, dan sungai Gajahwong. Ketiga sungai tersebut tebingnya dalam sehingga mampu menampung aliran air hujan dan air limbah. Dengan demikian, kota Yogyakarta tidak dilanda banjir. Apalagi tanah di kota Yogyakarta berpasir, dan letaknya miring $1^{\circ}$ ke arah selatan. Oleh karena itu, jika diatur dan dikembangkan sebaik-baiknya, jalur alur air di kota ini tidak menimbulkan masalah. Suatu sumber (Darmosugito, 1956: 23) menyebutkan bahwa batas wilayah kota Yogyakarta kuno adalah:

1. bagian utara daerah Jetis -- Samirono;

2. bagian timur: daerah Samirono -- Lowano;

3. bagian selatan: daerah Lowano -- Bugisan; dan

4. bagian barat: daerah Bugisan -- Jetis.

Pada tahun 1932 wilayah kota Yogyakarta meliputi: Gondokusuman - Batikan Karangkajen - Jogokaryan - Suryodiningratan - Suryaden - Pingit - Cemarajajar (Tirtakopesoema, 1932: 46, Lampiran Peta).

Berdasarkan kajian atas peta tersebut di atas, dan sumber-sumber lain, diketahui bahwa unsur-unsur pokok kota Yogyakarta pada dekade ketiga abad XX adalah sebagai berikut.

1. Kraton dengan bagian-bagiannya yang kesemuanya berada di dalam lingkungan cepuri.

2. Alun-Alun Utara dan Selatan dengan pohon-pohon beringinnya, baik berupa beringin kurung maupun beringin yang ditanam di tepi alun-alun.

3. Benteng yang melindungi kraton dan wilayah di sekitamya. Benteng tersebut semula mempunyai lima pintu gerbang, jagang, dan tulaktala yang sekarang masih ada.

4. Masjid Agung sebagai masjid jami' kerajaan. Di samping itu ada beberapa masjid keeil seperti masjid Suranatan, dan masjid Watu.

5. Taman Sari yang merupakan taman kerajaan dan sekaligus berfungsi sebagai salah satu tempat pertahanan.

6. Benteng Vredeburg yang pada tahun $1761 \mathrm{M}$ masih berupa dinding tanah diperkuat dengan tiang-tiang glugu (Hatmosuprobo, t.t.: 174). Pembangunan benteng tersebut baru selesai pada tahun 1788 .

7. Pasar Beringharjo yang merupakan pasar utama. 
8. Jalan Maliabara yang merupakan jalur jalan utama. Carey (1984:56) dalam kajiannya mengemukakan bahwa jalan yang membentang ke arah Gedung Keresidenan itu lebar, lurus, dan dinaungi deretan pohon tinggi di kanan kirinya. Dalam tembang Mijil tentang kota Yogyakarta juga disebutkan bahwa jalan-jalan di kota dinaungi pohon-pohon gayam.

9. Kepatihan yang bangunan utamanya menghadap ke selatan.

10. Pal Putih disebut juga Tugu yang berada di ujung jalan Maliabara. Bangunan asli Tugu ini runtuh pada tahun 1867 karena gempa bumi. Adapun bangunan Tugu yang sekarang dibangun pada masa pemerintahan Sultan HB VII.

11. Panggung Krapyak yang terletak $\pm 1 \mathrm{~km}$ lurus di selatan gapura Nirbaya. Bangunan setinggi $12 \mathrm{~m}$ ini dahulu digunakan dalam acara perburuan.

12. Pemakaman bagi penduduk kota. Kecuali pemakaman-pemakaman kuno di sekitar kota Yogyakarta bagi sultan dan para bangsawan, ada pemakaman lain di wilayah Ngampilan ( Peta kota Yogyakarta tahun 1800), di Pakuncen (Suryomiharjo, 1988: 50), serta di belakang Masjid Agung. Pemakaman bagi warga Eropa ditempatkan di sebelah timur pasar Beringharjo, dan kemudian di Kerkop. Pemakaman bagi masyarakat Cina ada di wilayah Pingit, dan kemudian di Gondokusuman.

13. Kali Larangan yaitu sungai buatan yang airnya diperoleh dari sungai Winanga. Air Kali Larangan dialirkan antara lain ke parit Masjid Agung, jagang, Taman Sari, lalu dibuang ke sungai Code.

14. Pura Pakualaman dengan alun-alun, pohon beringin, dan masjid.

15. Loji Kebon yaitu tempat kediaman Residen yang kemudian dilengkapi dengan kantor di sebelah utaranya.

16. Gereja Protestan yang berdiri di utara Loji Kebon, dan gereja Katolik yang berdiri di selatan benteng Vredeburg

17. Societeit de Vereneging atau Kamar Bola yang berdiri di selatan Loji Kebon

18. Pemukiman penduduk yang dapat dikenali dari toponim-toponim yang masih ada sekarang. Toponim tersebut antara lain adalah: Kadipaten, Panembahan, Kauman, Gamelan, Wirabrajan, Gandekan, Dagen, dan Jagalan. Warga asing juga mendapat permukiman tersendiri, yaitu: orang-orang Cina bermukim di Pacinan, orang-orang Arab bermukim di Sayidan, dan orang-orang Eropa bermukim di Loji Kecil, kemudian juga di Bintaran serta Kotabaru.

Di luar kota Yogyakarta banyak terdapat pesanggrahan yang dibangun oleh para sultan Yogyakarta. Ada di antaranya yang masih utuh, yaitu Ambarukma; ada yang tinggal sisa-sisanya, seperti Rejawinangun dan Semak; ada pula yang saat ini tinggal nama belaka. Di samping pesanggrahan, di luar kota Yogyakarta juga terdapat toponim yang untuk sementara diduga merupakan perkampungan para pandai besi. Toponim tersebut adalah Pandean. 


\section{Kota Yogyakarta dalam Perbandingan}

Dalam membahas Yogyakarta dari segi arkeologi perkotaan, sudah seharusnya jilka pembicaraan tidak dilepaskan dari kota-kota kuno yang ada di sekitarnya, sebab kota Yogyakarta adalah salah satu dari mata rantai perkembangan kota-kota di Jawa, khususnya di pedalaman. Sebagaimana diketahui, ibukota kerajaan Mataram-Islam pertama kali adalah di Kota Gede. Ibukota yang pertama ini berfungsi sampai wafatnya Sultan Agung. Kemudian penggantinya, yaitu Susuhunan Amangkurat I, memindahkan ibukota ke Plered sampai ia meloloskan diri dari kraton yang kemudian diduduki Trunajaya. Tahun 1680 Susuhunan Amangkurat II mendirikan kota Kartasura yang berfungsi sampai tahun 1745, tatkala Susuhunan Pakubuwana II pindah ke Surakarta.

Jika kota Yogyakarta dibandingkan dengan Kota Gede, Plered, Kartasura, dan Surakarta, maka diperoleh hasil sebagai berikut.

1. Sebagai pusat pemerintahan, kcempat kota kuno tersebut juga memiliki kraton. Sama halnya dengan kraton Yogyakarta, kraton Surakarta juga mempunyai cepuri, dan juga menghadap ke utara. Mengenai tiga kraton yang lebih tua, data artefaktual yang menggambarkan arah hadap, dan bentuk arsitekturalnya, belum ditemukan. Sementara ini, kekosongan tersebut diisi dengan data toponim yang di ketiga situs tersebut menunjukkan posisi yang sama, yaitu: toponim Alun-Alun ada di sebelah utara toponim Kedaton. Tulisan utusan-utusan Belanda yang berkunjung ke kraton Plered (Graaf, 1981:15; Goens, 1856:312) memperkuat penarikan interpretasi mengenai tata ruang kraton dan alun-alun.

2. Seperti halnya kraton Yogyakarta, kraton Surakarta dan Kartasura juga memiliki sepasang alun-alun. Akan tetapi, baik data toponim, data dari sumber tertulis, maupun data piktorial tidak menunjukkan adanya dua alun-alun di kedua kota yang lebih tua. Di Plered di selatan toponim Kedaton hanya ada toponim Pungkuran dan Kebonan.

3. Kota Surakarta, Kartasura, dan Kota Gede selain mempunyai tembok keliling kraton, juga mempunyai benteng. Unsur yang sama juga terdapat di Kartasura, Plered, dan Kota Gede sebagaimana tampak dari data arkeologis, data piktorial, dan interpretasi foto udara (Nayati, 1987). Meskipun demikian, struktumya tidak dapat diketahui lagi, karena parahnya kerusakan, bahkan suatu bagian dari jagang luar Kota Gede dipakai untuk perumahan.

4. Masjid Agung di keempat kota kerajaan Mataram-Islam juga ada, dan menempati lokasi yang sama.

5. Di kota Surakarta terdapat beberapa taman, baik yang berada di luar lingkungan kraton, maupun yang berada di dalam kraton Surakarta. Di Kartasura taman diduga dahulu menempati situs Gunung Kunci, sedang di Plered tempat bersenang-senang diwujudkan dalam bentuk danau buatan dengan membendung 
sungai. Di Kota Gede tidak terdapat data tentang taman, tetapi karena ada jabatan abdi dalem juru taman, maka diduga dahulu juga ada taman di Kota Gede.

6. Benteng Belanda hanya ada di Yogyakarta, Surakarta, dan Kartasura. Data tentang keberadaan benteng Belanda di Kartasura hanya dapat dilacak dari peta tua koleksi Pcrpustakaan Kraton Surakarta. Peta tersebut menggambarkan lokasinya, yaitu diseberang utara Alun-Alun Utara, seperti halnya di Surakarta dan Yogyakarta.

7. Pasar di keempat kota yang lebih tua itu juga menempati ruang yang mirip dengan lokasi pasar Beringharjo di Yogyakarta, yakni di utara kraton.

8. Aksis utara yang di kota Yogyakarta diwujudkan dalam bentuk Maliabara dan Tugu, di Surakarta juga muncul dalam bentuk yang mirip, meskipun tidak sejelas dan setegas aksis utara di kota Yogyakarta. Di ketiga kota yang lain hal tersebut belum kelihatan.

9. Kepatihan hanya tampak jelas lokasinya di kota Surakarta dan Yogyakarta.

10. Aksis selatan yang di Yogyakarta diwujudkan dalam bentuk jalan Gading sampai Panggung Krapyak. Di Surakarta aksis selatan tidak tampak, meskipun toponim Krapyak ( = hutan perburuan) juga ada di selatan kraton. Pada ketiga kota yang lebih tua, aksis tersebut tidak kelihatan, meskipun istilah krapyak sering disebutsebut dalam sumber sejarah tradisional.

11. Di Surakarta ada beberapa pemakaman umum yang diduga merupakan pemakaman lama, misalnya Utaralaya. Menarik perhatian, bahwa tempat-tempat tersebut ada di pinggir kota seperti di Yogyakarta. Adapun di kota pembanding lainnya belum didapat-kan data tentang letak pemakaman umum.

12. Di empat kota yang lebih tua kelihatan ada usaha untuk mengalirkan air ke dalam kraton atau lingkungannya ( Ricklefs, 1978: 31; Graaf, 1987: 14-15; Behrend, 1982: 143).

13. Adanya Pura Pakualaman di Yogyakarta dan lokasinya, hanya dapat dibandingkan dengan Surakarta yang mempunyai Pura Mangkunegaran.

14. Tempat tinggal Residen dan bangunan-bangunan atau fasilitas lain untuk masyarakat Belanda, hanya dapat dibandingkan dengan Surakarta saja.

15. Pemukiman penduduk di keempat kota yang lebih tua menunjukkan model pengelompokan yang sentrifugal, sebagaimana terlihat dari lokasi toponimtoponim, misalnya: Kauman, Gerjen, Singosaren, Wirokerten, Gandekan, Sampangan. Pemukiman untuk orang asing baru muncul di Kartasura yang mempunyai Pacinan.

16. Adanya jaringan jalan antar kota kuno dan di dalam kota-kota itu sendiri sebagaimana dapat diinterpretasikan dari Babad ing Sangkala. Babad itu menyebutkan bahwa Susuhunan Amangkurat I bercengkerama dengan isterinya mengendarai kereta, dan orang-orang Mataram membuat kereta tertutup dari kayu angsana, serta orang-orang membuat pintu gerbang di Kaliajir beserta jalan-jalan besarnya (Babad ing Sangkala pupuh 1 bait 62,71 ). Demikian pula berita yang 
ditulis oleh utusan Belanda menyebutkan adanya jaringan jalan kecil dan jalan besar di Mataram (Graaf, 1985: 117 -- 118: Goens, 1856: 312).

Dari perbandingan-perbandingan tersebut di atas, kelihatan ada persamaan unsur fisik kota antara Yogyakarta dan keempat kota pendahulunya. Persamaan itu meliputi beberapa hal sebagai berikut.

1. Organisasi ruang. Kota berpusat pada kraton yang juga merupakan salah satu bukti adanya organisasi politik. Kraton, alun-alun, masjid agung, serta pasar membentuk civic-center yang kelihatannya berpola linier. Di samping itu, jaringan jalan yang merupakan prasarana transportasi juga ikut membentuk struktur fisik kota, karena menghubungkan ruang-ruang yang ada secara intern maupun ekstern. Pemakaman tampak ditempatkan di areal Masjid Agung, dan pinggiran kota. Permukiman penduduk ditata menyebar mengelilingi civic center dengan kelompok agraris pada bagian periferi.

2. Organisasi sosial. Dari toponim-toponim yang ada dapat dilihat adanya organisasi-organisasi sosial dalam bentuk kelompok perundagian dan profesi lain, serta kelompok berdasarkan golongan etnik.

3. Aspek pertahanan. Empat di antara lima kota yang dibicarakan, mempunyai tembok keliling rangkap yang melindungi kraton sendiri, melindungi kraton beserta wilayah di sekitarnya. Plered hanya mempunyai satu tembok keliling. tetapi di ketiga sisinya dikelilingi oleh danau buatan.

Di samping persamaan, juga ada beberapa perbedaan, di antaranya sebagai berikut.

1. Denah benteng Kota Gede mempunyai bentuk yang unik, berbeda dengan kotakota yang lebih muda. Dari sisi yang lain, benteng-luar kota Yogyakarta menunjukkan struktur yang jelas berfungsi untuk pertahanan dan keamanan. Hal ini berbeda dengan benteng-luar pada kota-kota yang lain.

2. Alun-Alun Utara dan Selatan baru muncul di kota Surakarta, meskipun prototipe Alun-Alun Selatan sudah ada di Kartasura.

3. Aksis Utara - Selatan dengan kraton sebagai pusatnya baru mulai muncul pada kota Surakarta. Pada kota-kota sebelumnya aksis tersebut belum tampak sama sekali. Di Yogyakarta aksis tersebut tampak jelas dan tegas.

4. Permukiman untuk etnik asing baru muncul di Kartasura, sedang di Surakarta dan Yogyakarta bertambah jenisnya. Dari toponim kelompok profesi dan perundagian tampak bahwa jenis-jenis pekerjaan yang dilakukan di Surakarta dan Yogyakarta lebih bervariasi daripada di ketiga kota lainnya.

\section{Kesimpulan dan Gagasan}

Setelah melakukan pembahasan, maka dapat ditarik bebcrapa kesimpulan sebagai berikut. 
1. Tinjauan terhadap kota Yogyakarta secara arkeologis tidak lepas kaitannya dengan kota-kota pendahulunya.

2. Kota Yogyakarta merupakan mata rantai terakhir dalam rangkaian perkembangan kota-kota kerajaan di Jawa.

3. Keutuhan Yogyakarta sebagai kota kuno dari segi arkeologis harus dijaga, antara lain dengan menumbuhkan apresiasi masyarakat terhadap peninggalanpeninggalannya. Selain itu, juga diusulkan diadakan Perda untuk menunjang Monumenten Ordonnantie.

Dalam rangka pembicaraan tentang kota Yogyakarta sebagai aset pariwisata, dikemukakan beberapa gagasan sebagai berikut.

1. "Menjual" keunikan arkeologis kota Yogyakarta sebagai salah satu aset wisata budaya untuk memperpanjang lama tinggal wisatawan.

2. "Menghidupkan" kembali bangunan-bangunan kuno, dan pemukiman kuno dengan jalan revitalisasi atau refungsionalisasi secara keseluruhan atau parsial, untuk "dijual" sebagai aset pariwisata.

\section{KEPUSTAKAAN}

Anonim, tt. Babad Sala, Ms. Reksopustoko Mangkunegaran.

1983. Survey Arkeologi Islam di DIY, Balai Arkeologi Yogyakarta.

Basyir Z.B., 1987. Mohammad, Kota Gede Kuno. Studi Pola Tata Kota dan Kehidupan Masyarakatnya, skripsi Sarjana Arkeologi UGM,Yogyakarta.

Behrend, Timothy Earl, 1982. Kraton and Cosmos in Traditional Java, thesis Master University of Wisconsin, Madison,

Carey, P.B.R., Jalan Malioboro (Garland Bearing Street). The Etymology and Historical Origins of a Much Misunderstood Yogyakarta Street Name, dalam Archipel no. 27, hlm. 51 -- 62.

Darmosoegito, Kota Jogjakarta 200 Tahun, Jogjakarta, t.p.: 1956.

Elisseeff, Nikita, 1980. Physical Lay-out, dalam The Islamic City. Paris: UNESCO., hlm. 90 -- 103. 
Goens, R van, 1856. Reijsbeschrijving van den Weg uit Samarang, nae de Konincklijke Hoofdplaets Mataram, dalam BKI deel 4, hlm. 307-350.

Graaf, H.J.de, 1985. Awal Kebangkitan Mataram (terj.), Jakarta: Grafiti Press.

Grafiti Press

1987. Desintegrasi Mataram di bawah Mangkurat I (terj.), Jakarta:

Hatmosuprobo. Suhardjo, Kota Yogyakarta dan benteng Vredeburg, dalam Rencana Pelestarian dan Pengembangan Benteng Vredeburg, jilid II, Yogyakarta.

Poensen,C., 1901. Mangkubumi Ngajogjakarta's Eerste Sultan, BKI XIII.

Ricklefs, M.C., 1974. Jogjakarta under Sultan Mangkubuini 1749 - 1792 (diss.), London: Oxford University Press.

1976. Modern Javanese Historical Tradition. A Study of an Original Kartasura Chronicle and Related Materials, London.

Sidharta - Eko Budihardjo, 1989. Konservasi Lingkungan dan Bangunan Kuna Bersejarah di Surakarta. Yogyakarta: Gadjah Mada University Press.

Sirjamaki. John, 1964. The Sociology of Cities, New York: Random House.

Suryo, Djoko, tt. Kota-kota di Jawa pada Abad 17--19. ceramah pada Proyek Javanologi, Yogyakarta.

Suryomihardjo, Abdurrachman, 1986. Kota Yogyakarta 1880 -- 1930. Suatu Tinjauan Historis Perkembangan Sosial, diss. UGM, Yogyakarta.

Tirtakoesoema, Soedjana, 1932. De ommegang van de Kangjeng Kjahi Toenggoel Woeloeng, dalam Djawa 12, hlm. 61 -- 65.

Weber, Max, 1958. The City, New York: The Free Press.

Zoetmulder. P.J.. 1982. Old Javanese - English Dictionary, part I, Martinus Nijhoff. 


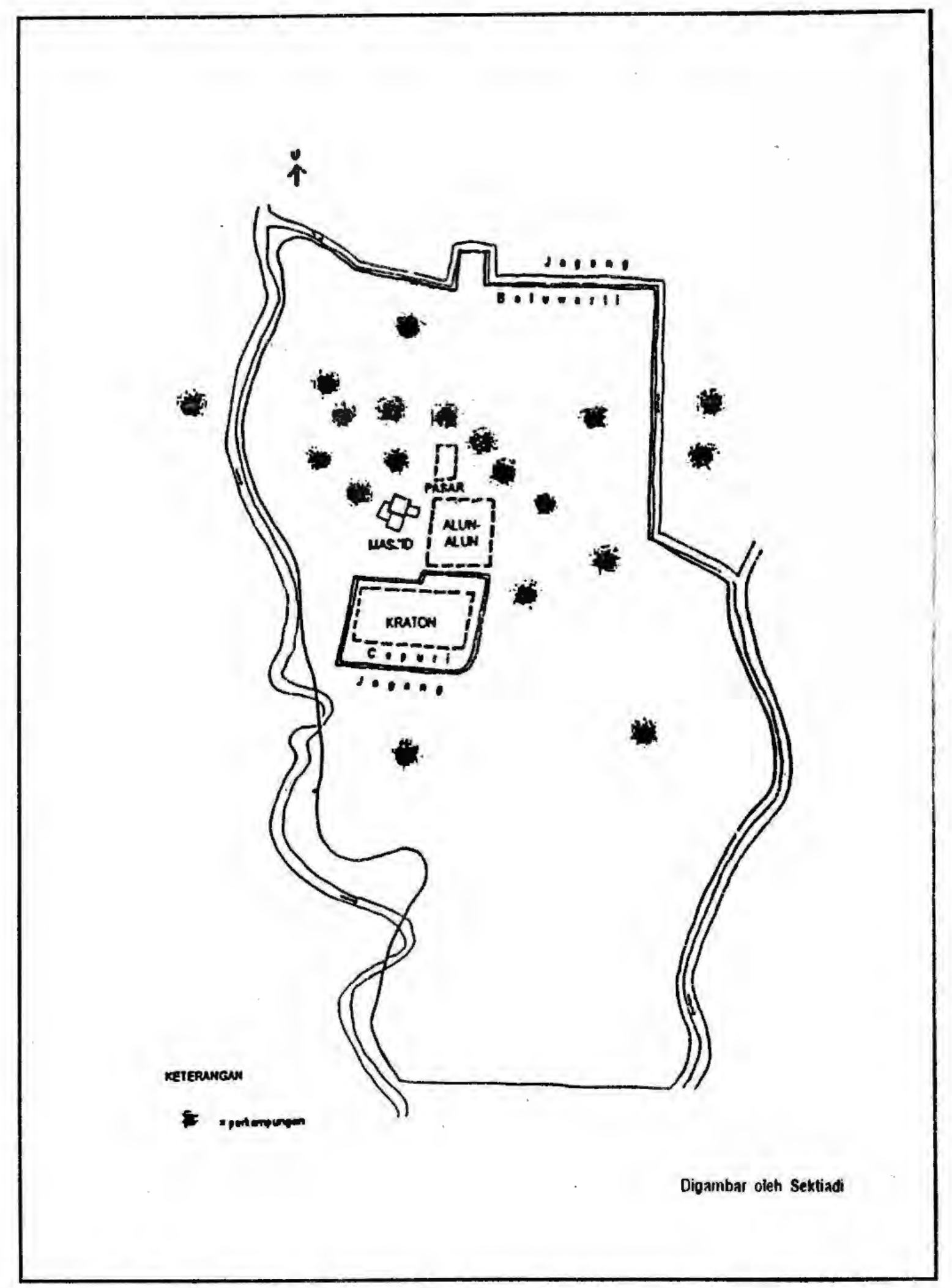

REKONSTRUKSI TATA RUANG SKEMATIS KOTAGEDE 


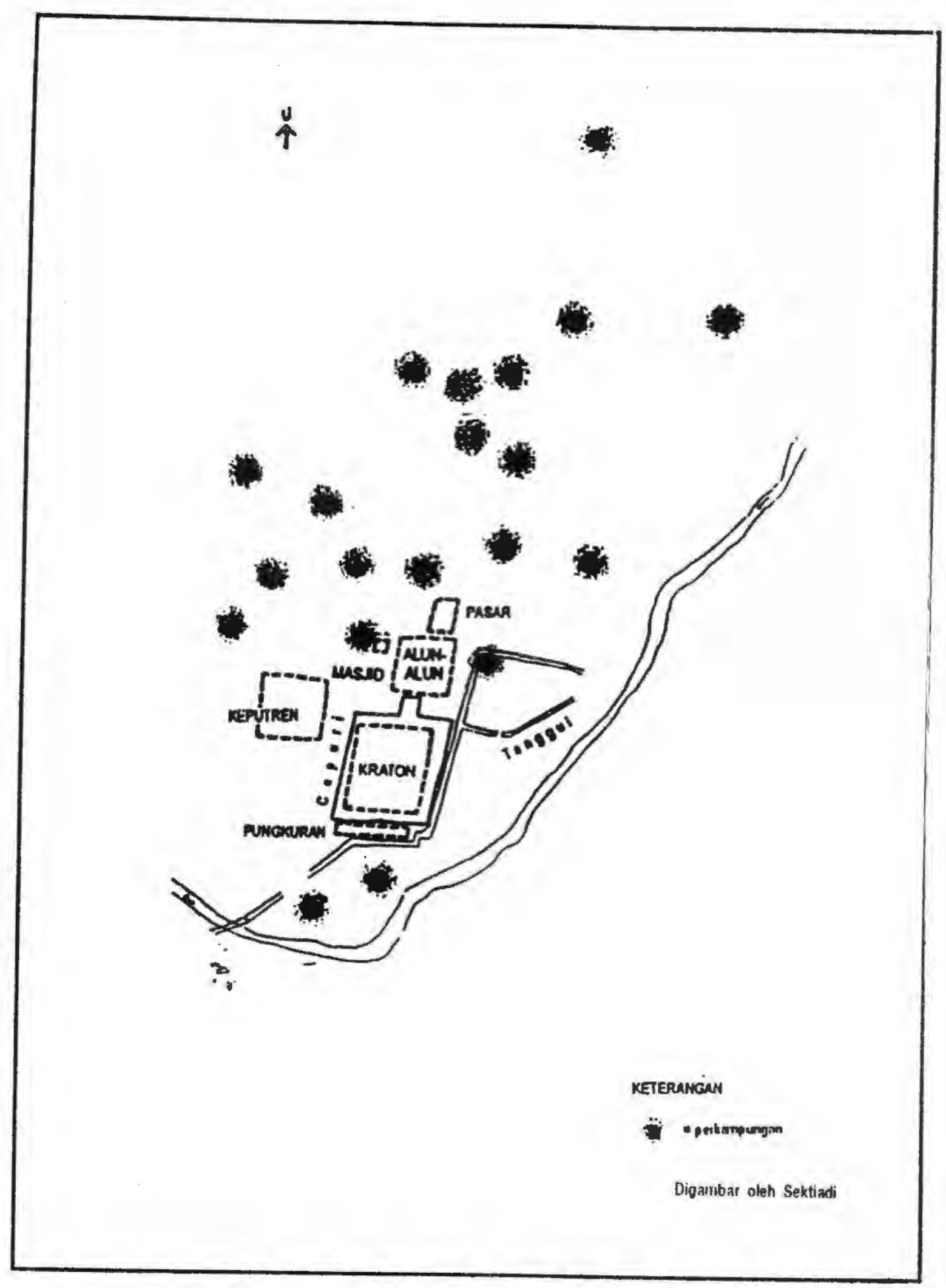

REKONSTRUKSI TATA RUANG SKEMATIS PLERED 


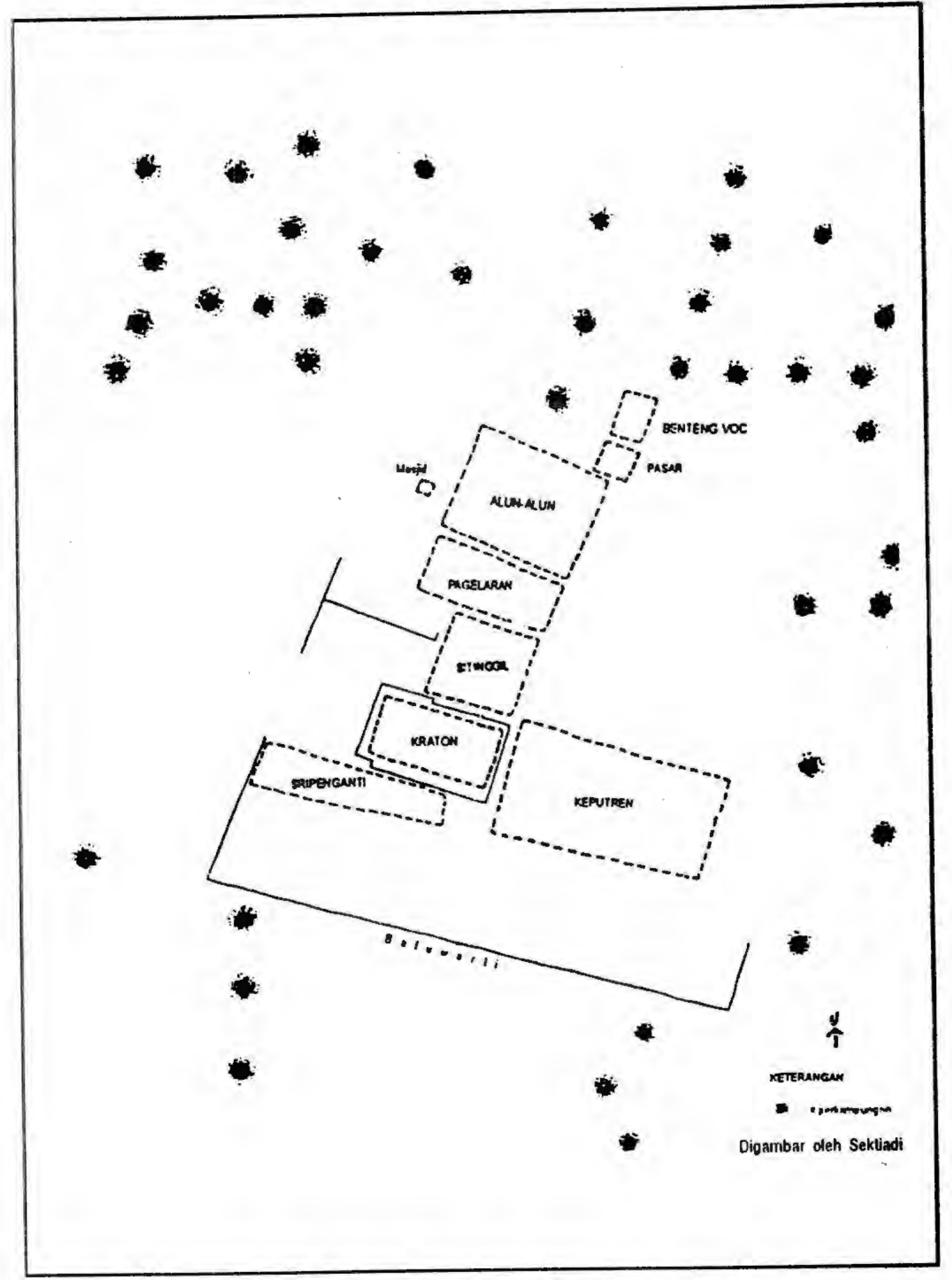

REKONSTRUKSI TATA RUANG SKEMATIS KARTASURA 


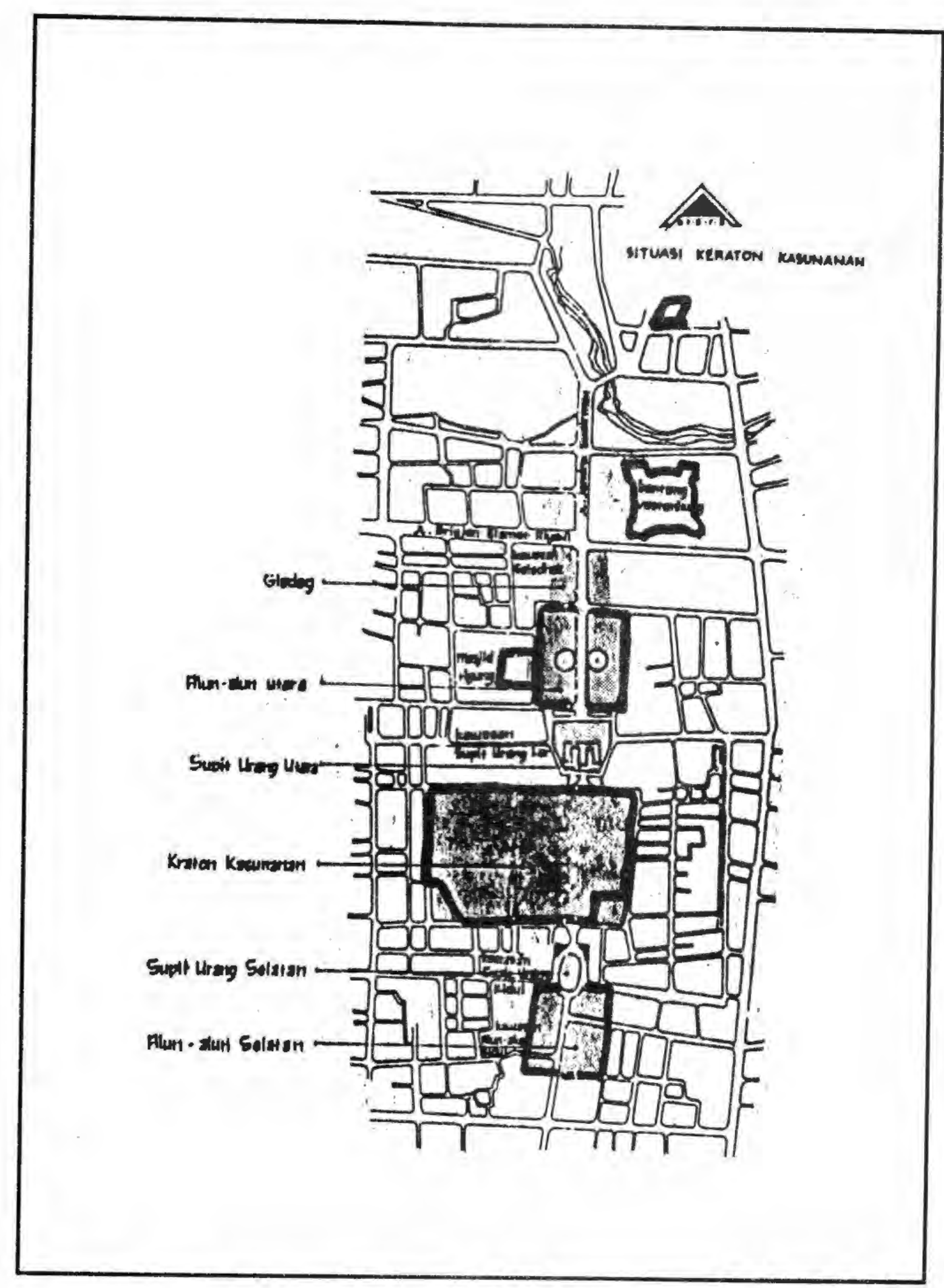

KELETAKAN KRATON SURAKARTA DAN KOMPONEN-KOMPONEN DI SEKITARNYA 


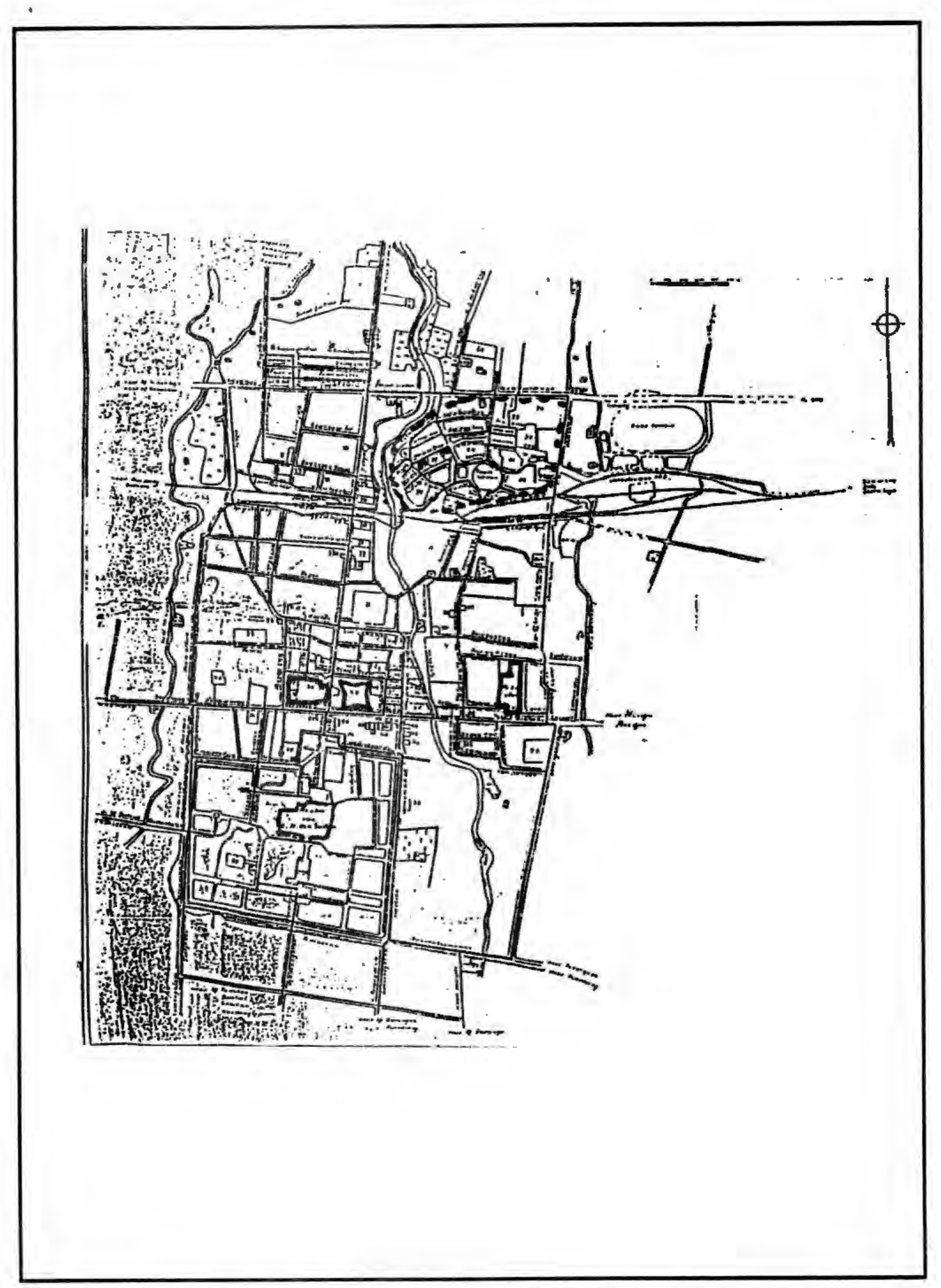

KELETAKAN KRATON YOGYAKARTA DAN KOMPONEN-KOMPONEN DI SEKITARNYA 